\title{
Uric acid effects on in vitro models of rheumatoid inflammatory and autoimmune, processes
}

\author{
ROBERT A. TURNER, EDWARD J. PISKO, CARLOS A. A GUDELO, \\ GRACE B. COUNTS, SUSAN L. FOSTER, AND WILLIAM J. TREADWAY
}

From the Rheumatology Section, Department of Medicine, Bowman Gray School of Medicine, Wake Forest University, Winston-Salem, NC, USA

SUMMARY A neutrophil monolayer system was used to study the effects of uric acid on neutrophil-aggregate interactions important in rheumatoid inflammation. No effect on immunoglobulin $\mathrm{G}$ aggregate phagocytosis was seen, but hyperuricaemic levels of uric acid were associated with an enhancement of phagocytosis-induced release of the azurophilic granular enzyme $\beta$-glucuronidase. A trinitrophenyl-coupled mononuclear leucocyte rheumatoid factor plaqueforming assay was utilised to study uric acid effects on polyclonal activation of immunocompetent cells. Low levels of uric acid enhanced and high levels suppressed this system. Hyperuricaemia may enhance some aspects of rheumatoid inflammation, while uric acid may modulate an important component of rheumatoid autoimmunity.

Rheumatoid arthritis is a highly prevalent inflammatory disease characterised by autoimmune immunological processes. Gout is a commonly occurring metabolic disease associated with systemic hyperuricaemia which only occasionally coexists with rheumatoid arthritis. ${ }^{1}$ The present study was performed to determine whether uric acid modulating effects on rheumatoid inflammatory and autoimmune processes occur, since these effects might help to explain the infrequent simultaneous occurrence of these 2 relatively widespread rheumatological conditions. Uric acid effects on rheumatoid inflammatory processes were examined in an in-vitro system utilising neutrophil monolayers and immunoglobulin $G$ (IgG) aggregates. The effects of uric acid on immunocompetent cells were studied in a system in which cells producing rheumatoid factor (RF) were polyclonally induced by haptenated mononuclear leucocytes.

\section{Materials and methods}

All studies were approved by the institutional clinical research practices committee. Informed consent was obtained from all participating subjects and all research was carried out according to the principles of the Declaration of Helsinki.

Accepted for publication 1 April 1982.

Correspondence to Robert Turner, MD, Bowman Gray School of Medicine, Winston-Salem, NC 27103, USA).
For the neutrophil-aggregate studies normal human polymorphonuclear leucocytes were suspended at 5 $\times 10^{6} / \mathrm{ml}$ concentration in Dulbecco's phosphate buffered saline (PBS) containing $10 \%$ autologous serum. Monolayers were prepared by placing $2.5 \mathrm{ml}$ of this cell suspension in $35 \times 10 \mathrm{~mm}$ plastic Petri dishes, incubating them for $45 \mathrm{~min}$ at $37^{\circ} \mathrm{C}$, and washing gently with room temperature PBS. Cells/monolayer were determined by counting cells/standardised grid under an inverted microscope. $1.5 \mathrm{ml}$ of a solution containing PBS, $10 \%$ serum, and either, $0,4,8$, or 12 $\mathrm{mg} / \mathrm{dl}$ uric acid (obtained from Fisher Scientific Company) were placed on the freshly prepared cell monolayers, which were then incubated for $30 \mathrm{~min}$ at $37^{\circ} \mathrm{C}$. The supernatants were then removed, and for the phagocytosis studies ${ }^{51} \mathrm{Cr}$-labelled IgG aggregates $(2.4 \mathrm{mg} / \mathrm{ml})$ were then added to the monolayers, which were incubated for $30 \mathrm{~min}$, and cells/monolayer and $\mathrm{mg}$ of aggregated $\mathrm{IgG} /$ monolayer were then determined by methods previously described. ${ }^{2}$ For enzyme studies unlabelled IgG aggregates were used, and fluid was aspirated from the monolayers for measurement of supernatant enzyme activity. The cell layer and remaining fluid were detergent-lysed and assayed for enzyme release by standard methods previously described. ${ }^{3}$

Studies inducing rheumatoid factor producing cells were performed as previously described. ${ }^{4}$ Peripheral blood mononuclear leucocytes were obtained by venipuncture on healthy adult volunteers. 60 to $100 \mathrm{ml}$ 
of heparinised blood was obtained, and cells were isolated on a Ficoll-Hypaque gradient. ${ }^{5}$ These cells were washed twice in Hepes-buffered Hanks's balanced salt solution (Grand Island Biological Company, Grand Island, NY), pH 7·8. Wright stain morphology revealed the cells to be $90 \%$ lymphocytes and $10 \%$ monocytes. Cells were $98 \%$ viable as determined by trypan blue dye exclusion after separation and washing. Washed mononuclear leucocytes were coupled to 2,4,6-trinitrobenzene sulphonic acid (Sigma, St Louis, MO) by Seldin and Rich's modification ${ }^{6}$ of Shearer's technique. ${ }^{7} 5 \times 10^{6}$ normal mononuclear leucocytes were cocultured with $1.25 \times 10^{6}$ TNP-coupled mononuclear leucocytes in a $5 \% \mathrm{CO}_{2}$ humidified atmosphere at $37^{\circ} \mathrm{C}$ in $17 \times 100 \mathrm{~mm}$ polystyrene culture tubes (Falcon 2001, Cockeyville, MD). Culture media consisted of $10 \mathrm{ml}$ of Roswell Park Memorial Institute (RPMI)-1640 (Flow Laboratories, Rockville, MD) supplemented with $1 \%$ antibiotic-antimycotic (GIBCO, Grand Island, NY), $2 \mathrm{mM}$ L-glutamine (GIBCO, Grand Island, NY), and $10 \%$ pooled, heat-inactivated $\left(30-\mathrm{min}, 56^{\circ} \mathrm{C}\right)$ human $\mathrm{AB}$ serum (GIBCO, Grand Island, NY). Uric acid was added to culture medium at a concentration of 4,8 , or 12 $\mathrm{mg} / \mathrm{dl}$. The medium was adjusted to $\mathrm{pH} 7 \cdot 2$ prior to the addition of cells and remained at this level throughout these and the previous monolayer studies. Cultures were fed $1 \mathrm{ml}$ of supplemented media on days 2 and 5 .

Rheumatoid-factor-producing cells were assayed on day 7 by a modification of the plaque-forming cell assay of Dosch and Gelfand. ${ }^{89}$ Human autologous red cells to be used as indicator cells in the assay were obtained at the time of lymphocyte separation and stored as a $50 \%$ solution in RPMI- 1640 at $4^{\circ} \mathrm{C}$ until use. These cells were coupled to heat-aggregated IgG obtained by dissolving human pooled Cohn fraction II IgG (US Biochemical, Cleveland, $\mathrm{OH}$ ) in normal saline at a concentration of $10 \mathrm{mg} / \mathrm{ml}$ and heating this solution at $63^{\circ} \mathrm{C}$ for $20 \mathrm{~min}$. Heat-aggregated IgG at a concentration of $5 \mathrm{mg} / \mathrm{ml}$ was coupled to the red cells with chromic chloride by the method of Sweet and Welborn. ${ }^{10}$ Monolayers of these cells were prepared on flat bottom 96-well cluster plates (Dynatech Laboratories, Alexandria, VA) with poly-L-lysine (Sigma, St Louis, MO). Plates containing $50 \mu \mathrm{l}$ of poly-L-lysine $(25 \mu / \mathrm{ml})$ per well were incubated at $37^{\circ} \mathrm{C}$ for $30 \mathrm{~min}$ and washed 3 times with PBS pH 7.4. $100 \mu \mathrm{l}$ of the $5 \%$ red cell suspension was added to each well and plates were centrifuged at $1000 \mathrm{rpm}$ for $5 \mathrm{~min}$ and then incubated at $37^{\circ} \mathrm{C}$ for 1 hour. Unbound red cells were eluted and monolayers were overlayed with $75 \mu$ l of RPMI-1640 until used. Monolayers were then inspected with an inverted microscope and only intact monolayers were used.

Cultures were used on day 7 if there was $\geqslant 90 \%$ viability before the assay. Cell viability, $\mathrm{pH}$, and yield were unaffected by the addition of uric acid to cultures. Cultured mononuclear leucocytes $\left(10^{4}\right.$ to $10^{5}$ cells) were added to each well containing the red cell monolayers after 2 washings with RPMI-1640. Guinea-pig serum was used as a source of complement and was obtained by cardiac puncture and stored at $-70^{\circ} \mathrm{C}$. This serum was adsorbed with the red cells at $0^{\circ} \mathrm{C}$ for $60 \mathrm{~min}$, diluted $1: 20$ in normal saline, and $25 \mu \mathrm{l}$ of this solution was added to each well. Plates were then incubated at $37^{\circ} \mathrm{C}$ for 1 hour. Plaques were counted with an inverted microscope. Five wells were counted per culture. Specificity of the assay for IgG was determined by successfully competitively inhibiting the assay with aggregated IgG.

Statistical analysis of experimental data was performed by standard methods. One-way analysis of variance was performed on the data, and Tukey's multiple comparison test was used to test the significance of all possible comparisons between groups.

\section{Results}

As shown in Table 1 adequate numbers (mean \pm SEM $\times 10^{6}=3 \cdot 44 \pm 0 \cdot 82$ ) of neutrophils remained on the monolayers throughout the neutrophilaggregate studies. As previously reported, ${ }^{11}$ adherence of these cells was not significantly $(p<0.05)$ affected by incubation with IgG aggregates or by the addition of increasing concentrations of uric acid to the system. As shown in Table 1 the uptake of ${ }^{51} \mathrm{Cr}$ labelled IgG aggregates (specific activity 78472 $\mathrm{cpm} / \mathrm{mg} \mathrm{IgG)} \mathrm{by} \mathrm{neutrophil} \mathrm{monolayers} \mathrm{calculated} \mathrm{as}$ $\mu \mathrm{g} \mathrm{IgG/monolayer} \mathrm{was} \mathrm{not} \mathrm{affected} \mathrm{by} \mathrm{the} \mathrm{increasing}$ concentrations of uric acid used in these studies. Additional calculations using $\mu \mathrm{g} \mathrm{IgG/neutrophil} \mathrm{or}$ $\mathrm{cpm} / \mathrm{monolayer}$ or /neutrophil also showed no differences in the phagocytic capacities of neutrophils exposed to aggregates in the presence of $0,4,8$, or 12 $\mathrm{mg} / \mathrm{dl}$ of uric acid. (SI conversion: $\mathrm{mg} / \mathrm{dl} \times 0.01=$ g/l.)

Phagocytosis of the aggregates did not cause significant release of the cytoplasmic enzyme lactic dehydrogenase (LDH), and this release was not affected by increased concentrations of uric acid. There was, however, a significant $(p<0.05)$ effect on the release of the azurophilic lysosomal enzyme $\beta$-glucuronidase as shown in Fig. 1 . This effect was apparent at $4 \mathrm{mg} / \mathrm{dl}$ and reached statistical significance $(p<0.05)$ at 8 and $12 \mathrm{mg} / \mathrm{dl}$. Shown in Fig. 2 are the effects of similar concentrations of uric acid on the azurophilic and specific lysosomal enzyme, lysozyme. There is an apparent increase in release with increasing concentrations of uric acid, but this effect did not cause a statistically significantly different 
Table 1 Effect of uric acid on neutrophil monolayer: phagocytosis of heat-aggregated IgG

\begin{tabular}{|c|c|c|c|c|}
\hline \multirow{2}{*}{$\begin{array}{l}\text { Uric acid } \\
\text { concentration } \\
(m g / d l)\end{array}$} & \multicolumn{3}{|c|}{$\mu g$ heat aggregated IgG/neutrophil monolayer } & \multirow[t]{2}{*}{ Mean $\pm S E M^{*}$} \\
\hline & Expt 1 & Expt 2 & Expt 3 & \\
\hline \multirow[t]{2}{*}{0} & 423 & 709 & 422 & $620 \pm 67$ \\
\hline & 858 & 826 & 402 & \\
\hline \multirow[t]{2}{*}{4} & 763 & 443 & 482 & $761 \pm 137$ \\
\hline & 1346 & 925 & 610 & \\
\hline \multirow[t]{2}{*}{8} & 1005 & 581 & 479 & $616 \pm 88$ \\
\hline & 715 & 465 & 455 & \\
\hline \multirow[t]{2}{*}{12} & 991 & 674 & 466 & $706 \pm 104$ \\
\hline & $\begin{array}{l}1039 \\
(3 \cdot 36 \pm 0 \cdot 22)\end{array}$ & $\begin{array}{l}610 \\
(2 \cdot 22 \pm 0 \cdot 06)\end{array}$ & $\begin{array}{l}458 \\
(4 \cdot 92 \pm 0 \cdot 17)\end{array}$ & $(3.44+0.82)$ \\
\hline
\end{tabular}

( ) Neutrophils/monolayer $\times 10^{6} \pm$ SEM for each of 3 separate experiments (expts).

*No statistically significant $(p<0 \cdot 05)$ differences betwesn groups.

SI conversion: $\mathrm{mg} / \mathrm{dl} \times 0 \cdot 01=\mathrm{g} / \mathrm{l}$.

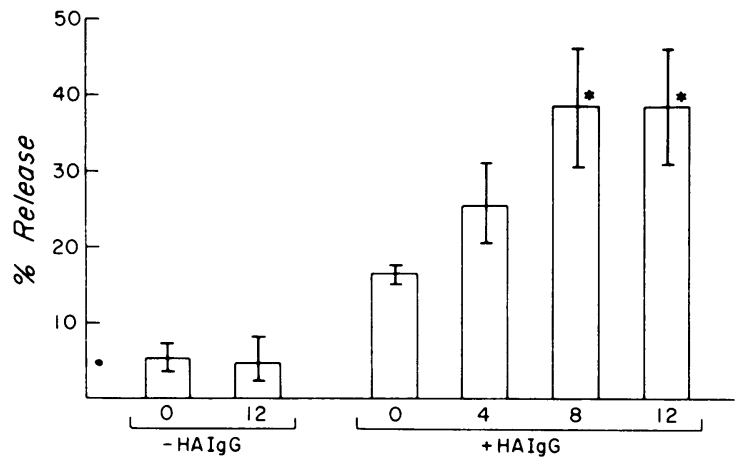

lysozyme release under the conditions of our study.

The results of experiments done to determine the effects of increasing concentrations of uric acid on the trinitrophenyl-coupled mononuclear-leucocyteinduced polyclonal activation of lymphocytes to produce rheumatoid factor are shown in Fig. 3. In these experiments rheumatoid-factor-producing cells were generated after coculturing normal and TNPhaptenated mononuclear leucocytes. Uric acid at a concentration of $4 \mathrm{mg} / \mathrm{dl}$ significantly $(p<0 \cdot 01)$

Uric Acid Concentration ( $\mathrm{mg} / \mathrm{dl}$ )

Fig. 1 The effect of uric acid on IgG aggregate-induced release of $\beta$-glucuronidase by neutrophil monolayers. Bars represent mean $\pm S E M$ enzyme release on 5 determinations in the absence (-) and presence $(+)$ of heat-aggregated immunoglobulin $G(\mathrm{HAIgG})$. Asterisks $\left(^{*}\right)$ indicate release statistically significantly different from control values.

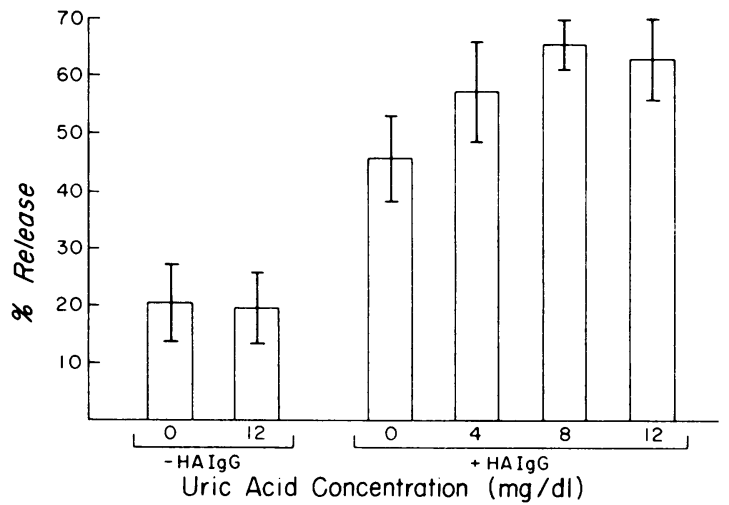

Fig. 2 The effect of uric acid on IgG aggregate-induced release of lysozyme by neutrophil monolayers. Bars represent mean $\pm S E M$ enzyme release on 5 determinations in the absence (-) and presence (+) of heat-aggregated immunoglobulin G (HAIgG).

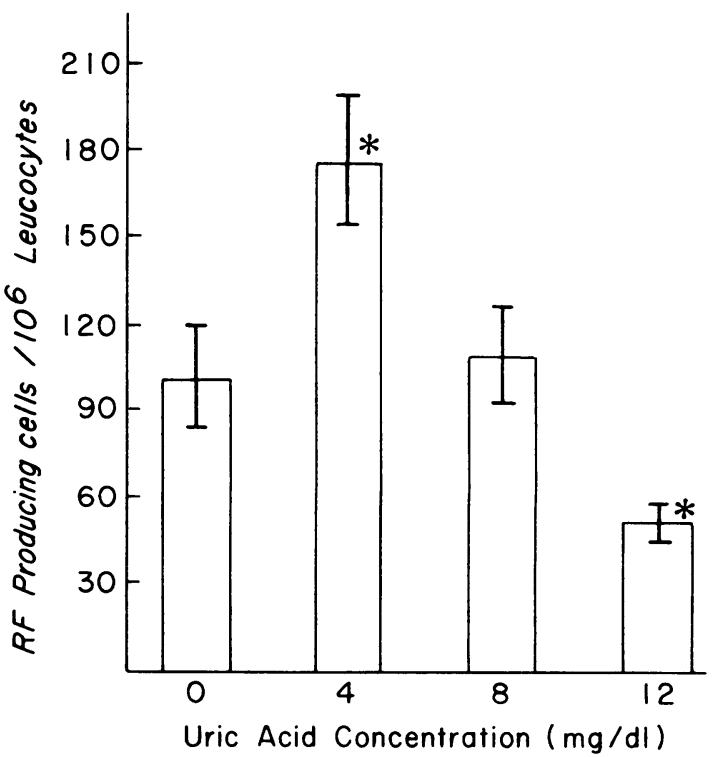

Fig. 3 The effect of uric acid on the induction of rheumatoid-factor-producing cells. The data are represented as the mean $\pm S E M$ of 3 experiments on separate individuals. Asterisks $\left({ }^{*}\right)$ indicate cultures statistically significantly different from controls. 
increased the numbers of rheumatoid-factorproducing cells detected in these cultures when compared to control cultures without added uric acid. Cultures containing $8 \mathrm{mg} / \mathrm{dl}$ of uric acid were no different from control cultures containing no added uric acid, but cultures containing $12 \mathrm{mg} / \mathrm{dl}$ of uric acid had significantly $(p<0.01)$ less rheumatoid-factorproducing cells than control cultures without added uric acid.

\section{Discussion}

These studies suggest that hyperuricaemia does not affect the phagocytosis of IgG aggregates, which has been thought ${ }^{12}$ to be an important contributing factor to the inflammation occurring in the joints of patients with rheumatoid arthritis. This finding is in keeping with that of Malawista et al. ${ }^{13}$ who reported a similar lack of effect on phagocytosis using uric acid, human neutrophils, and different particles. Their study demonstrated augmented LDH release in the presence of silica crystals but not bacteria. They attributed this augmented release to inhibition by uric acid of the binding of albumin but not IgG to membrane surfaces and subsequent increased susceptibility to crystal-induced phagolysosome lysis and cell death. We have extended these studies in a system which does not cause early cell death but does result in the selective release of lysosomal enzymes. It is clear from our studies that high levels of uric acid enhance the release of azurophilic granular enzymes. This effect did not seem to be mediated through crystal formation as (1) none were detected by polarised light microscopic examination of test solutions; (2) there was no effect on enzyme release by the highest concentrations of uric acid used alone with the cells; and (3) crystallisation may not be expected to occur under the experimental conditions employed in these studies. ${ }^{1415}$

High levels of uric acid clearly inhibit the ability of our normal mononuclear cell system to be activated to produce rheumatoid factor. This activation may be a model for the response of the rheumatoid patient's immunological system to the factors responsible for the initiation and persistence of the rheumatoid process. This process often results in invasion of cartilage by masses of activated cells and the erosion of cartilage and bone by the rheumatoid pannus. Lussier and deMedicis ${ }^{16}$ studied the effects of hyperuricaemia on adjuvant arthritis which had been used as an in-vivo animal model for the study of rheumatoid joint disease processes. Their studies showed weak uric acid effects on the primary inflammatory stage but marked inhibitory effects on the secondary destructive stage of this experimental model. Our studies suggest similar findings with an enhancement of inflammatory but an inhibition of immunological processes by high levels of uric acid. Although there have been a number of recent clinical reports ${ }^{17-21}$ of coexisting gout and rheumatoid arthritis, our study is the first to describe uric acid effects on in-vitro neutrophil and lymphocyte functional systems designed as models of rheumatoid inflammation and autoimmunity. Future clinical studies might prospectively examine the effects of hyperuricaemia on these aspects of rheumatoid disease processes and determine their effects on the $x$-ray progression which is seen in many patients with rheumatoid arthritis.

This project was supported in part by grants from the Arthritis Foundation and the Easter Seal Research Foundation.

\section{References}

1 Ramay D, Abdalla A M, Newton D R L, et al. Coexistent rheumatoid arthritis and tophaceous gout: a case report. Ann Rheum Dis 1981; 40: 427-9.

2 Turner R, Counts G, Mashburn H, et al. Drug and rheumatoid factor effects on the uptake of immunoglobulin $G$ aggregates. Inflammation 1980; 4: 55-63.

3 Turner R, Martin M, Schroff J, et al. Neutrophil enzyme activities in rheumatoid inflammation. Inflammation 1979; 3: 319-27.

4 Pisko E J, Foster S L, Turner R A. Induction of autoantibody producing cells after the co-culture of haptenated and normal human mononuclear leukocytes. Proc Soc Exp Biol Med 1981; 168: 131-136.

5 Böyum A. Isolation of mononuclear cells and granulocytes from human blood. Isolation of mononuclear cells by one centrifugation and of granulocytes by combining centrifugation and sedimentation at $1 \mathrm{~g}$. Scand J Clin Lab Invest 1968; 21 (suppl 97): 77-89.

6 Seldin M F, Rich R R. Human immune responses to haptenconjugated cells. I. Primary and secondary proliferative responses in vitro. J Exp Med 1978; 147: 1671-83.

7 Shearer G M. Cell-mediated cytotoxicity to trinitrophenylmodified syngeneic lymphocytes. Eur J Immunol 1974; 4: 527-33.

8 Dosch $\mathrm{H} \mathrm{M}$, Gelfand $\mathrm{E} \mathrm{W}$. In vitro induction and measurement of hemolytic plaque forming cells in man. J Immunol Methods 1976; 11: 107-16.

9 Dosch H M, Gelfand E W. Generation of human plaque forming cells in culture: tissue distribution, antigenic and cellular requirements. J Immunol 1977; 118: 302-8.

10 Sweet G H, Welborn F L. Use of chromium chloride as the coupling agent in a modified plaque assay cells producing antiprotein antibody. $J$ Immunol 1971; 106: 1407-10.

11 Turner R, Counts G, Johnson J, et al. Neutrophil interactions with particulate materials. In: Willoughby D A, Giroud J P, eds. Inflammation: Mechanisms and Treatment. Lancaster: MTP Press, 1980: 347-53.

12 Hollander J L, McCarty D J Jr, Astorga G, et al. Studies on the pathogenesis of rheumatoid joint inflammation. $I$. The ' $R$. A. Cell' and a working hypothesis. Ann Intern Med 1975; 62: 271-80.

13 Malawista S E, Blaricom G V, Gretulla S B, et al. The phlogistic potential of urate in solution. Studies of phagocytic process in human leukocytes. Arthritis Rheum 1979; 22: 728-36.

14 Fried F A, Vermeulen C W. Artificial uric acid concretions and observations on uric acid solubility and supersaturation. Invest Urol 1964; 2: 131-44. 
342 Turner, Pisko, Agudelo, Counts, Foster, Treadway

15 Klinenberg J R, Bluestone R, Schlosstein L, et al. Urate deposition disease. How is it regulated and how can it be modified? Ann Intern Med 1973; 78: 99-111.

16 Lussier A, deMedicis R. Inhibition of adjuvant arthritis in the rat by an oxonate diet: sequential studies. J Rheumatol 1977; 4: 369-76.

17 Talbott J H, Alyman R D, Yu T E. Gouty arthritis masquerading as rheumatoid arthritis or vice versa. Semin Arthritis Rheum 1978; 8: 77-114.
18 Jessee E F, Toone E, Owen D S, et al. Coexistent rheumatoid arthritis and chronic tophaceous gout. Arthritis Rheum 1980; 23: 244-7.

19 Rizzoli A J, Trujeque L, Bankhurst A D. The coexistence of gout and rheumatoid arthritis: case reports and a review of the literature. J Rheumatol 1980; 7: 316-24.

20 Waterworth R F. The effect of allopurinol therapy on coexistent gout and rheumatoid arthritis. Arthritis Rheum 1981; 24: 103-4.

21 Wallace $O \mathrm{~J}$, Klinenberg J R, Morhaim D, et al. Coexistent gout and rheumatoid arthritis. Arthritis Rheum 1979; 22: 81-6. 